\title{
Nutrition and Catering
}

$\mathrm{T}$ HE report of the Nutrition Committee of the British Medical Association, issued in November 1933 , and reviewed in NATURE of January 13, 1934 (133, 53), was designed to determine the minimum weekly expenditure on foodstuffs which would maintain in health and working capacity families of various sizes. A supplementary pamphlet is now issued to be of practical help to the housewife*

The translation of food schedules into appetising meals was first undertaken by teachers of domestic science who attended the summer school of the Board of Education in London in 1934. The B.M.A. specimen diet No. 16 for a man, wife and three children was the chosen model. Improvements were introduced to make more variety without increasing cost. Menus for the principal meals for three weeks have been planned, and the dishes for each day illustrated in colour. Shopping lists of food quantities and recipes are included, and a table of food values. Owing to local and seasonal variations in prices the total cost is not here estimated, but in the original report the average price was assessed at $5 s, 5 \frac{1}{2} d$. per man weekly.

The American Medical Association has for many years concerned itself with teaching the public the principles of hygiene, including proper nutrition. We welcome this evidence that the B.M.A. is awakening to the fact that the fight against malnutrition is at the present time the most important problem in preventive medicine. The manner in which the information is presented in this pamphlet is simple and attractive, and beyond criticism, but the nature of

" "Family Meals and Catering." Pp. $27+3$ plates. (London: British Medical Association, 1935.) $6 d$. the diet recommended is not so faultless. The principles of the newer knowledge of nutrition have not been applied ; there is close adherence to the obsolete standards of the pre-vitamin era with the focus too exclusively on calories and an unnecessarily high total protein ratio. The supply of vitamins and minerals is sub-optimal. The proportion of fat, and therefore of fat-soluble vitamins, is admittedly low.

The sum allowed weekly for fresh fruits and vegetables has been cut down from the $2 s$. $6 d$. allowed in the first report to a scanty $1 s$. 1ld. for a family of five; the amount of vitamin $\mathrm{C}$ is further reduced by pickling some vegetables. No advisory note is inserted that wholemeal flour and bread provide for the same money better value than white cereal products in respect to quality of protein, vitamins and mineral salts. If, as is probable, white bread, etc., are used, 60 per cent of the total calories are derived from over-refined foodstuffs lacking vitamins and de $f i$ ient in mineral salts, and leading inevitably to malnutrition. Where money is short the best slogan is that advocated by Prof. Sherman, 'no calories without vitamins'.

The health value of this diet would be greatly improved by an increase of butter or milk and of green vegetables; by a decrease in sugar; by replacing white cereals, sago, etc., by whole cereals ; by decreasing the total cereals and increasing the amount of potatoes. As a basis for planning healthy and inexpensive diets Dr. Mikkel Hindhede's book on health by correct and simple diet, reviewed in NATURE of June 22, 1935 (135, 1016), might with advantage be consulted.

\section{Universities and Business Training}

\begin{abstract}
$\mathrm{A}^{\mathrm{T}}$ T the discussion on "The Universities and Business" arranged by the Department of Industrial Co-operation, Section F (Economic Science and Statistics), at the British Association meeting at Norwich on September 5, Dr. J. A. Bowie discussed the need for more intimate co-operation and suggested that British university schools of business were supplying a negligible percentage of the men required for administrative positions in industry and commerce. Dr. Bowie estimated that over the whole of British industry there were about one million suitable appointments for the business graduate. If the British schools of business were supplying the administrative grade of employee at the same rate as the replenishment in the closed professions, they should be producing about 40,000 graduates annually instead of the actual $200-300$.

It was not suggested that such graduates were entitled at once to a responsible managerial post, but the importance of finding them a progressive post leading to such positions was stressed. Dr. Bowie urged that the main reason for the low output of graduates from the university schools of business in
\end{abstract}

Great Britain lay in lack of close working association between education and business. $\mathrm{He}$ considered that academic ideas had influenced too largely the com. mercial courses in Great Britain, which should be modelled on those of the medical school rather than the arts course.

University education for business should aim at giving the student a knowledge of the facts and principles relating to the nature and functions of business and our economic institutions ; the capacity for disciplined thinking, for logical analysis and reasoning with respect to the problem of business and of modern society; facility in oral and written expression; an acquaintance with the operating tools of management such as general and cost account ing ; and personal effectiveness including the capacity for job analysis and co-operation. At present Dr. Bowie considered that insufficient attention was paid to the development of facility in oral and written expression, the operating tools of management, and the development of personal effectiveness. The employer attached primary importance to the possession of desirable traits of personality and 
character and to the capacity to co-operate effectively with others in the attainment of common ends, and the university should supplement its scholarship test by stimulating the development of such personal qualities, by inculcating right attitudes towards life and work and emphasising the need for disciplined habits of thought.

Dr. Bowie suggested further that the determination of the ideal curriculum for business training awaited the result of an inquiry which had yet to be made, and that industry in its turn should pay more attention to the training of its recruits and to definite schemes of promotion. The tendency for the universities to become too exclusively recruiting and training grounds for the professions was socially undesirable and economically disastrous.

Dr. Bowie's address provoked a lively discussion, particularly with reference to the curriculum of the university schools of business, and the place of economics in such training. Opinion was strongly expressed that it would be disastrous to confuse the academic study of economics and research in this field with preparation for a business career, and that the two were best kept distinct. Dr. Bowie himself suggested that economics was probably best studied at a final stage of a business training rather than as a basic subject for such training.

The whole value of such courses of training for business was challenged in the discussion and opinion was expressed that, provided the recruit entered business with a trained mind, it did not greatly matter whether that training had been given in a science or in an arts course. Business could always utilise the trained mind. Against this view it was pointed out that the transfer of knowledge and training was not high and such a policy might involve serious waste. A plea was made that something in the nature of refresher courses in business subjects on the lines of the post-graduate courses now arranged annually in a number of technical colleges and universities might be useful, and it is possible that the university schools of business may render some of their most important services to industry in the provision of such courses for those actually engaged in responsible administrative work. Somewhat surprisingly, despite Dr. Bowie's remarks, no reference was made to the tendency for administrative work itself to be regarded as a profession or at least to be influenced increasingly by professional ideals.

\section{Educational Topics and Events}

Aberdeen.--Dr. William Hamilton Fyfe, principal and vice-chancellor, Queen's University, Kingston, Ontario since 1930, has been appointed principal of the University of Aberdeen, in succession to the Very Rev. Sir George Adam Smith, whose resignation will take effect on October 31. Dr. Hamilton Fyfe was, in 1919-30, headmaster of Christ's Hospital.

Cambridge.-D. H. Valentine, of St. John's College, has been appointed to the Frank Smart University studentship in botany.

At Girton College the Founders' Memorial Lecture will be given by Sir Frank Dyson on Saturday, October 26, at the College. The title of the lecture will be "The Discovery of the Solar System".
At Christ's College the following members of the College have been elected honorary fellows: Prof. Arthur Hutchinson, Master of Pembroke College and emeritus professor of mineralogy; Prof. J. Graham Kerr, M.P., emeritus professor of zoology, University of Glasgow, formerly fellow of the College; Prof. G. H. F. Nuttall, emeritus professor of biology and director of the Molteno Institute of Parasitology, formerly fellow of the College; Dr. A. W. Rogers, lately director of the Geological Survey, Union of South Africa, president of the Royal Society of South Africa.

With the withdrawal of the opposition, the offer of $£ 10,000$ to the University by Sir John Siddeley for the promotion of aeronautical research has been accepted by the Regent House. The non-placet was withdrawn in a fly-sheet in which the signatories explained that their attitude, when the offer was originally made in July, was that the money should be used only for work of a fundamental and nonmilitary character. Prof. Melvill Jones, it is stated, gave in effect the assurance required, for he said that all work done in his department was published in the ordinary way and that Sir John's gift was unconditional. The supporters of the non-placet add that, since the promotion of human knowledge and welfare is the special responsibility of the University, "it should not even appear to be associated with work that has the destruction of civilization as its object". The suggestion is also made that the "University should define its position on the whole question of military, commercial and secret research, and that an early opportunity should be given for a discussion of this question".

Oxford.-Dr. J. G. Priestley has been appointed deputy for the professor of physiology during the vacancy caused by Sir Charles Sherrington's retirement.

Dr. F. G. Hobson has been appointed Litchfield lecturer in medicine and Mr. H. A. B. Whitelocke Litchfield lecturer in surgery.

Dr. J. Marschak, All Souls' College, formerly of the Universities of Heidelberg and Kiel, has been appointed director of the new Institute of Statistics for five years from October 1.

Dr. L. H. D. Buxton has been appointed reader in physical anthropology for seven years from October 1 .

Federal aid for schools in the poorer regions of the United States is being urgently demanded on the ground that the existing system of school finance, based on the small school district, has, in many localities, completely broken down. "Our American school system is fighting for its very existence," said a member of Congress recently when introducing a Bill for establishing such a measure of federal participation in public instruction as would ensure a reasonable standard of education for every boy and girl in the Union. In support of his contention, he cited statistics showing that salaries of teachers amounting to more than 57 million dollars are in arrears, and that outstanding salary warrants noncashable or subject to heavy discounts amount to nearly 50 millions. The resources available in the different States for the maintenance of schools differ very widely, and the years of industrial depression have strengthened the hands of the politicians who hold that the Federal Government should now take more responsibility for education. 